\title{
Antioxidant, Enzyme Inhibitory and Calcium Oxalate Anti-crystallization Activities of Equisetum telmateia Ehrn.
}

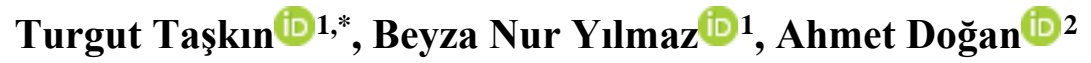 \\ ${ }^{1}$ Department of Pharmacognosy, Faculty of Pharmacy, Marmara University, Istanbul, Turkey \\ ${ }^{2}$ Department of Pharmaceutical Botany, Faculty of Pharmacy, Marmara University, Istanbul, Turkey
}

\begin{abstract}
Equisetum L. is the only genus of the Equisetaceae family, which commonly known as horsetails, in English and atkuyruğu or kırkkilit in Turkish. In traditional medicine, Equisetum telmateia Ehrh. is used in diseases of the urinary system, such as pyelonephritis, prostatic hypertrophy, and cystitis. Besides, this species is known to be used by humans to treat kidney stones or kidney sand. The extracts were obtained from the aerial parts of the E. telmateia using three different extraction methods (maceration, Soxhlet, ultrasonic bath) and their antioxidant (ABTS, CUPRAC), anti-urease and anticholinesterase activities were examined. Also, calcium oxalate anticrystallization activity of Soxhlet methanol extract showing strong antioxidant activity was determined. Soxhlet methanol extract exhibited stronger ABTS radical scavenging $(0.0676 \mathrm{mM}$ Trolox $/ \mathrm{mg}$ extract $)$ and cupric ion reducing/antioxidant (4.351 $\mathrm{mM}$ Trolox/mg extract) activity than other extracts. Soxhlet methanol $(65.528 \%)$ and maceration methanol $(61.965 \%)$ extracts showed the strongest anticholinesterase activity. In the anti-urease assay, it was found that Soxhlet petroleum ether extract $(15.302 \%)$ had the highest anti-urease activity. Furthermore, the data obtained showed that the Soxhlet methanol extract had high efficacy in the nucleation and aggregation phase of calcium oxalate crystals. These results prove that Soxhlet methanol extract has antioxidant, anticholinesterase and anti-crystallization capabilities. Therefore, this extract can be used in the future as an antioxidant and anticholinesterase agent as well as the treatment and / or prevention of stone formation.
\end{abstract}

\section{ARTICLE HISTORY}

Received: March 21, 2020

Revised: April 18, 2020

Accepted: July 08, 2020

\section{KEYWORDS}

Equisetum telmateia,

Anti-urease,

Anticholinesterase,

Anti-crystallization

\section{INTRODUCTION}

Equisetum L. is the only genus of the Equisetaceae family, which commonly known as horsetails, in English and atkuyruğu or kırkkilit in Turkish. While there are approximately 32 known species in the world, there are 7 species in the Flora of Turkey. They are usually perennial plants rich in cell wall silica, growing in moist and wet places. Equisetum telmateia Ehrh. species has the widest distribution among Equisetum species in regions such as Europe, West Asia, Northwest Africa and North America [1]. Equisetum species is often used in traditional medicine for various ailments as a medicinal tea. They are very effective in the

CONTACT: Turgut Taşkın $₫$ turguttaskin@marmara.edu.tr $\equiv$ Department of Pharmacognosy, Faculty of Pharmacy, Marmara University, Istanbul, Turkey 
treatment of urinary tract infections, cardiovascular diseases, respiratory infections, and medical skin conditions. In traditional medicine, E. telmateia is used in diseases of the urinary system, such as pyelonephritis, prostatic hypertrophy, and cystitis. Besides, this species is known to be used by humans to treat kidney stones or kidney sand. The aerial parts of the $E$. telmateia are used in the treatment of stomach pain, abdominal pain, peptic ulcers, eczema, acne and rheumatism in Anatolia [2-4]. E. telmateia species contain flavonoids and phenolic acids. E. telmateia has been known neuroprotective, antimicrobial, anti-inflammatory, diuretic antiulcerogenic and potent antioxidant effects. Phenolic compounds are known to be effective in these biological activities of the plant [5].

Free radicals are compounds that contain one or more unpaired electrons. Since free radicals contain unpaired electrons, they can easily react with biological molecules in the organism, such as lipids, nucleic acid, protein, and carbohydrates. Therefore, these radicals are effective in the formation of various diseases formation of various diseases including cardiovascular diseases, tissue damage, ischemic heart diseases, cancer, atherosclerosis, central nervous system damage, nervous disorders, obesity, gastritis, arthritis and aging in humans [68]. As with other aerobic organisms, free radicals occur as a result of naturally occurring metabolic events in humans. These free radicals are eliminated by antioxidant defense mechanisms. Antioxidants inhibit lipid peroxidation by inhibiting the peroxidation chain reaction or by collecting reactive oxygen species. Therefore, antioxidants play an important role in both protection and treatment against these various ailments caused by free radicals, by preventing DNA damage, reducing the abnormal increase in cell division [9]. Increased intake of exogenous antioxidants reduces the effects caused by these radicals. Natural antioxidants are commonly found in food and medicinal plants, and they have anti-inflammatory, anti-aging, anti-atherosclerosis and anticancer effects [10-12].

Alzheimer's disease (AD) is a progressive neurodegenerative disease [13]. Some studies are promising for this disease, but unfortunately, there is currently no cure for the disease [14, 15]. Helicobacter pylori (H. pylori) infection is among the world's most common infections. $H$. pylori infection is a common worldwide infection that is an important cause of peptic ulcer and gastric cancer [16, 17]. Antibiotic therapy for the treatment of $H$. pylori infections has many disadvantages, such as lack of effectiveness, development of resistance, gastrointestinal side effects and possible recurrence of the disease. Among the difficulties for H. pylori eradication, increased resistance to antibiotic regimens currently used in therapy is a major concern, suggesting that therapeutic strategies need to be changed. As a result, there is a growing interest in the development of new antimicrobial therapeutic agents, preferably with a higher chance of natural treatment against $H$. pylori [18].

Stone formation in the kidney and urinary tract is a serious pathology that is important today and can lead to kidney failure if left untreated. It is known that it affects an average of 4$20 \%$ of the population. In recent years, the incidence of the disease has also been increasing [19]. A kidney stone is a total of crystallization stages consisting of nucleation, growth and aggregation stages of crystals in saturated urine in epithelial cells in renal papillae. These crystals are essentially available in three different forms: calcium oxalate monohydrate $\left(\mathrm{CaC}_{2} \mathrm{O}_{4} . \mathrm{H}_{2} \mathrm{O}, \mathrm{COM}\right.$ or whewellite), calcium oxalate dihydrate $\left(\mathrm{CaC}_{2} \mathrm{O}_{4} .2 \mathrm{H}_{2} \mathrm{O}, \mathrm{COD}\right.$ or weddellite) or calcium oxalate trihydrate $\left(\mathrm{CaC}_{2} \mathrm{O}_{4} .3 \mathrm{H}_{2} \mathrm{O}\right.$, COT or caoxite). Calcium oxalate monohydrate $(\mathrm{COM})$ and calcium oxalate dihydrate (COD) form the main structure of kidney stones. Calcium oxalate trihydrate (COT) is rarely found in kidney stones. Calcium oxalate monohydrate (COM) is the thermodynamically most stable form and has a high affinity for renal tubular cells. As a result, it has the effect of initiating stone formation in the urinary area and kidney. Therefore, the number of studies on the inhibition of calcium oxalate monohydrate crystals has been increasing in recent years [20-22]. Although there are important advances in 
the pathophysiology and treatment of kidney stones, it is highly likely that kidney stones may occur again. The painful and high cost of surgical methods and drug treatments led to new searches in treatment. Studies on natural products have been focused on the prevention and recurrence of this disease [23, 24].

The purpose of this study was to evaluate in vitro antioxidant, anti-urease, anticholinesterase and calcium oxalate anti-crystallization activities of different extracts from E. telmateia aerial parts.

\section{MATERIAL and METHODS}

\subsection{Identification of Plant Material}

E. telmateia was taxonomically identified by Assist. Prof. Dr. Ahmet DOĞAN. The voucher specimens, representative samples of the plant material, were archived in the herbarium of the Faculty of Pharmacy, Marmara University and documented with the herbarium number of MARE:20465.

\subsection{Preparation of E. telmateia Extracts}

Aerial parts of E.telmateia were dried at $25^{\circ} \mathrm{C}$ in the shade. Dried parts of the plant were treated with a mechanical grinder (Renas, RBT1250) for fine powder and proper weight. The three extraction methods were performed to gain crude extracts from the aerial parts of the plant.

Maceration: Plant powder (45 g) was extracted with the use of petroleum ether, chloroform and methanol until colorless.

Soxhlet extraction: 45 grams of plant powder was extracted in the Soxhlet apparatus with petroleum ether, chloroform and methanol.

Ultrasonic bath extraction: 45 grams of plant powder were extracted in an ultrasonic bath with petroleum ether, chloroform and methanol. The nine different extracts from the plant were concentrated by a rotary vacuum evaporator. All the extracts obtained were stored at $4{ }^{\circ} \mathrm{C}$ for future analysis.

\subsection{ABTS ${ }^{+}$Radical Scavenging Assay}

$50 \mu \mathrm{L}$ of extracts prepared at different concentrations $(1-5 \mathrm{mg} / \mathrm{mL}), 50 \mu \mathrm{L}$ of ABTS ${ }^{+}$ working solution and $150 \mu \mathrm{L}$ distilled water were added on the prepared extracts. The mixture absorbance was determined against the reference at $734 \mathrm{~nm}$ for $6 \mathrm{~min}$. The control sample was prepared under the same conditions with the use of $50 \mu \mathrm{L}$ distilled water instead of experimental and standard materials. The control sample was daily measured. ABTS radical scavenging determination was applied to Trolox solutions prepared at different concentrations $(0.2-1 \mathrm{mM})$. The results of this study were given as $\mathrm{mM}$ Trolox/mg extract [25].

\subsection{Cupric Ion Reducing/Antioxidant Power (CUPRAC) Assay}

$60 \mu \mathrm{L} \mathrm{Cu}(\mathrm{II}) \times 2 \mathrm{H}_{2} \mathrm{O}, 60 \mu \mathrm{L}$ neocuproine and $60 \mu \mathrm{L}, \mathrm{NH}_{4} \mathrm{Ac}(1 \mathrm{M})$ were mixed. Then 60 $\mu \mathrm{L}$ of the extract and $10 \mu \mathrm{L}$ of ethanol were added to the mixture. after 60 min duration time, the mixture absorbance was spectrophotometrically measured at $450 \mathrm{~nm}$. CUPRAC values of the extracts were given as $\mathrm{mM}$ Trolox/mg extract [26].

\subsection{Anti-Urease Activity Assay}

Stock solutions were prepared from different extracts obtained from the plant and these solutions were diluted to prepare working solutions. A working solution $(100 \mu \mathrm{L})$ was taken and urease $(500 \mu \mathrm{L})$ was added on it. The mixture was incubated at $37^{\circ} \mathrm{C}$ for $30 \mathrm{~min}$. Then, $1100 \mu \mathrm{L}$ of urea was added to this mixture and kept in the incubator at $37^{\circ} \mathrm{C}$ for $30 \mathrm{~min}$. R 1 ( $1 \%$ phenol, $0.005 \%$ sodium nitroprusside) and $\mathrm{R} 2(0.5 \% \mathrm{NaOH}, 0.1 \%$ sodium hypochlorite) 
reagents were added to the mixture, respectively. After the incubation period at $37^{\circ} \mathrm{C}$ for $2 \mathrm{~h}$, the absorbance of samples was measured at $635 \mathrm{~nm}$ [27].

The $\%$ inhibition of urease was calculated by the formula:

$\%$ enzyme inhibition $\left.=\left[\left(\mathrm{A}_{0}-\mathrm{A}_{1}\right) / \mathrm{A}_{0}\right] \times 100\right]$

$\mathrm{A}_{0}$ : The absorbance of the control solution

A1: Absorbance of plant extracts and standard solutions.

\subsection{Anticholinesterase Activity Assay}

Inhibition activities of acetylcholinesterase (AchE) were measured using a microplate reader. Acetylcholinesterase is an enzyme source derived from electric fish, acetylthiokolin iodide was used as a substrate. Yellow-colored 5,5-dithiobis- (2-nitrobenzoic acid) (DTNB) was used for the measurement of activity. As a control, ethanol and galantamine, the alkaloid type drug isolated from the Galanthus plant, were used as controls. Briefly, the AchE $(20 \mu \mathrm{L})$ and different concentrations of extracts $(20 \mu \mathrm{L})$ were added to phosphate buffer solution ( $\mathrm{pH}$ 8.2 $0.1 \mathrm{M}, 40 \mu \mathrm{L}$ ). This mixture was incubated at $25^{\circ} \mathrm{C}$ for $10 \mathrm{~min}$. After incubation, DTNB $(100 \mu \mathrm{L})$ and AcI $(20 \mu \mathrm{L})$ as substrate were added to the mixture. The same procedure was applied to the galantamine used as standard. 5-thio-2-nitrobenzoic acid was spectrophotometrically measured at $412 \mathrm{~nm}$. Anticholinesterase activity of the extracts was calculated using the following equation as\% inhibition relative to control [28].

$$
\% \mathrm{I}=\left(\mathrm{A}_{\text {control }}-\mathrm{A}_{\text {sample }} / \mathrm{A}_{\text {control }}\right) \mathrm{x} 100
$$

\subsection{Crystallization Assay}

\subsubsection{Nucleation Assay (Turbidity Method)}

Solutions of calcium chloride $(5 \mathrm{mM})$ and sodium oxalate $(7.5 \mathrm{mM})$ were prepared, respectively, in a buffer containing Tris-HCI $0.05 \mathrm{M}$ and $\mathrm{NaCl} 0.15 \mathrm{M}$ at $\mathrm{pH} 6.5 .3 \mathrm{~mL}$ of calcium chloride and sodium oxalate solution was mixed with $1 \mathrm{~mL}$ of the extract at different concentrations. The mixture solution was mixed with vortex for 30 seconds. After the incubation period at $37^{\circ} \mathrm{C}$ for $30 \mathrm{~min}$. The absorbance of the solution was monitored at $620 \mathrm{~nm}$ [29].

\subsubsection{Aggregation Assay}

$\mathrm{CaOx}$ monohydrate $(\mathrm{COM})$ crystals were prepared by mixing calcium chloride and sodium oxalate at $50 \mathrm{mM}$. Both solutions were equilibrated to $60^{\circ} \mathrm{C}$ for 1 hour in a water bath. It was then kept in an incubator at $37^{\circ} \mathrm{C}$ for 1 night and then placed in the desiccant. COM crystals were used at a final concentration of $0.8 \mathrm{mg} / \mathrm{mL}$, buffered with buffer at $\mathrm{pH} 6.5 .3 \mathrm{~mL}$ of $\mathrm{CaOx}$ solution was mixed with $1 \mathrm{~mL}$ of the extract at different concentrations. The solution was mixed with vortex for 30 seconds. After the incubation period at $37^{\circ} \mathrm{C}$ for $30 \mathrm{~min}$ the absorbance of solution was monitored at $620 \mathrm{~nm}$ [29].

\subsubsection{Crystal Characterization}

The number, size and morphology of $\mathrm{CaOx}$ crystals was observed by light microscopy (40x magnification) in the presence and absence of extracts after nucleation and aggregation experiments [29].

\subsection{Statistical Analysis}

All the experiments were done in triplicates. The results of the antioxidant, anticholinesterase and anti-urease experiments were demonstrated as mean \pm SD. All the data were analyzed by the Graphpad Prism 5 program. Statistical differences between the study groups were analyzed using two-way analysis of variance (ANOVA) followed by Tukey's Multiple Comparison test and p-values less than 0.05 were considered statistically significant. 


\section{RESULTS and DISCUSSION}

\subsection{Antioxidant Activity}

The results of the ABTS assay showed that Soxhlet methanol $(0.0676 \mathrm{mM}$ Trolox/ $\mathrm{mg}$ extract) and maceration methanol $(0.0662 \mathrm{mM}$ Trolox $/ \mathrm{mg}$ extract) extracts exhibited the strongest ABTS radical cation scavenging activity. Also, it was found that petroleum ether extract obtained from ultrasonic bath and Soxhlet methods did not show ABTS activity. The Soxhlet methanol (4.351 mM Trolox/mg extract) and maceration methanol $(3.826 \mathrm{mM}$ Trolox/mg extract) extracts exhibited stronger cupric reducing antioxidant activity than other extracts. In this study, it was found that the Soxhlet extraction technique is the most suitable method to get the most powerful ABTS and CUPRAC antioxidant activity. In addition, it was determined that the solvent with strong antioxidant activity was methanol in these assays.

The antioxidant and antifungal activity of dichloromethane, ethyl acetate, methanol and water extracts of the sterile stem of the plant was investigated. The methanol extract (IC50 12.92 $\mu \mathrm{g} / \mathrm{mL}$ ) was found to have stronger DPPH activity than dichloromethane (not detected), ethyl acetate $\left(\mathrm{IC}_{50} 50.90 \mu \mathrm{g} / \mathrm{mL}\right.$ ) and water (IC $5020.32 \mu \mathrm{g} / \mathrm{mL}$ ) extracts (Table 1). Also, antifungal activity of all extracts against Rhizopus stolonifer strain was not detected [30]. In our study, it was found that the Soxhlet ( $0.0676 \mathrm{mM}$ Trolox $)$ and maceration $(0.0662 \mathrm{mM}$ Trolox $)$ methanol extracts showed strong radical scavenging (ABTS) activity in parallel with this study. In another study, antioxidant activities of water and ethyl acetate extracts obtained from the aerial parts of the plant were evaluated by DPPH and TEAC methods. Besides, as a result of analysis of these extracts with HPLC-PAD-ESI/MS, it was found that both extracts contain flavan-3-ol, kaempferol and phenolic acid derivatives as major phenolic compounds. In this study, it was observed that ethyl acetate extract have higher DPPH (IC $500.018 \mathrm{mg} / \mathrm{mL})$ and TEAC $(342.8$ $\mathrm{mg}$ Trolox $/ \mathrm{mg}$ extract) activity than water extract $\left(\mathrm{IC}_{50} 0.455 \mathrm{mg} / \mathrm{mL} ; 11.00 \mathrm{mg}\right.$ Trolox $/ \mathrm{mg}$ extract) [31]. When the TEAC values of the ethyl acetate (342.8 $\mathrm{mg}$ Trolox) and methanol (0.0676 mM Trolox) extracts were compared, it was observed that the ethyl acetate extract had higher TEAC value than methanol extract. The different TEAC values may be due to used of the different solvent and the extraction method. Besides, harvesting the plant from different times and regions may have been effective in showing different ABTS (TEAC values) radical scavenging activity.

The antioxidant activities of aqueous, methanol and ethanol extracts of the aerial parts of E. telmateia have been previously investigated by the CUPRAC assay. In this study, it was found that ethanol (Abs:0.6 nm) extract had higher cupper reducing antioxidant activity than methanol (Abs:0.5 nm) and aqueous (Abs:0.2 nm) extracts [32]. In our study, it was determined that methanol extracts [especially Soxhlet methanol (4.351 mM Trolox)] obtained by three extraction techniques showed strong cupper reducing antioxidant activity in parallel with the literature study (Table 1).

\subsection{Urease Inhibitory Activity}

The percentage of inhibition of urease enzyme at $12.5 \mu \mathrm{g} / \mathrm{mL}$ concentration of different extracts was determined by using the Indophenol method and the results were shown in Table 2. Soxhlet petroleum ether $(15.302 \%)$ and maceration petroleum ether $(8.815 \%)$ extracts exhibited stronger anti-urease activity than other extracts. In the ultrasonic bath, chloroform $(4.531 \%)$ and methanol $(3.498 \%)$ extracts showed the best anti-urease activity. Comparing the activity results of all the extracts, the Soxhlet petroleum ether extract had the strongest antiurease activity and all extract showed lower activity than thiourea compounds $(70.05 \%)$. The Soxhlet extraction technique is the most suitable method to obtain the strongest anti-urease activity. It was also found that the most suitable solvent for obtaining strong anti-urease activity was petroleum ether. 
Table 1. The antioxidant activity of E. telmateia different extracts

\begin{tabular}{|c|c|c|c|c|c|c|}
\hline \multirow[t]{2}{*}{ Samples } & \multicolumn{3}{|c|}{ ABTS (mM trolox/mg extract) } & \multicolumn{3}{|c|}{ CUPRAC (mM trolox/mg extract) } \\
\hline & $\begin{array}{l}\text { Ultrasonic } \\
\text { bath }\end{array}$ & Maceration & Soxhlet & $\begin{array}{l}\text { Ultrasonic } \\
\text { bath }\end{array}$ & Maceration & Soxhlet \\
\hline Petroleum ether & NA & $\begin{array}{c}0.0063 \pm \\
0.004^{\mathrm{a}}\end{array}$ & NA & $\begin{array}{c}1.18 \pm \\
0.0412^{\mathrm{a}}\end{array}$ & $\begin{array}{c}1.086 \pm \\
0.03^{\mathrm{a}}\end{array}$ & $\underset{\mathrm{a}}{1.515 \pm 0.068}$ \\
\hline Chloroform & $\begin{array}{c}0.0003 \pm \\
0.001^{\mathrm{a}}\end{array}$ & $\begin{array}{c}0.0082 \pm \\
0.003^{\mathrm{b}}\end{array}$ & $\begin{array}{l}0.0103 \pm \\
0.0035^{\mathrm{a}}\end{array}$ & $\begin{array}{l}1.587 \pm \\
0.1513^{\mathrm{b}}\end{array}$ & $\begin{array}{c}1.576 \pm \\
0.03^{\mathrm{b}}\end{array}$ & $\underset{\mathrm{b}}{1.661 \pm 0.055}$ \\
\hline Methanol & $\begin{array}{l}0.0638 \pm \\
0.0011^{\mathrm{b}}\end{array}$ & $\begin{array}{l}0.0662 \pm \\
0.0016^{\mathrm{c}}\end{array}$ & $\begin{array}{l}0.0676 \pm \\
0.0013^{\mathrm{b}}\end{array}$ & $\begin{array}{l}2.791 \pm \\
0.0849^{c}\end{array}$ & $\begin{array}{c}3.826 \pm \\
0.20^{c}\end{array}$ & $4.351 \pm 0.014$ \\
\hline Ascorbic acid & $\begin{array}{l}0.013 \pm \\
0.001^{\mathrm{c}}\end{array}$ & $\begin{array}{c}00.013 \pm \\
0.001^{\mathrm{d}}\end{array}$ & $\begin{array}{c}0.013 \pm \\
0.001^{c}\end{array}$ & & & \\
\hline BHA & & & & $\begin{array}{c}1.83 \pm \\
0.0002^{\mathrm{d}}\end{array}$ & $\begin{array}{c}1.83 \pm \\
0.0002^{\mathrm{d}}\end{array}$ & $\begin{array}{c}1.83 \pm \\
0.0002^{\mathrm{d}}\end{array}$ \\
\hline
\end{tabular}

Values are mean of triplicate determination $(n=3) \pm$ standard deviation; Means with different superscripts (a-d) are significantly different, $p<0.05$; NA: not activity

Table 2. The anti-urease activity of different extracts of E.telmateia

\begin{tabular}{lccc}
\hline Samples & \multicolumn{3}{c}{ Enzyme inhibition percentage $(12.5 \mu \mathrm{g} / \mathrm{mL})$} \\
\cline { 2 - 4 } & Ultrasonic bath & Maceration & Soxhlet \\
\hline Petroleum ether & $2.62 \pm 2.3302^{\mathrm{a}}$ & $8.815 \pm 0.52^{\mathrm{a}}$ & $15.302 \pm 1.251^{\mathrm{a}}$ \\
Chloroform & $4.531 \pm 1.196^{\mathrm{b}}$ & $2.635 \pm 1.998^{\mathrm{b}}$ & $3.76 \pm 2.001^{\mathrm{b}}$ \\
Methanol & $3.498 \pm 3.57^{\mathrm{c}}$ & $6.149 \pm 3.1732^{\mathrm{c}}$ & $7.921 \pm 4.363^{\mathrm{c}}$ \\
Thiourea & $70.05 \pm 0.007^{\mathrm{d}}$ & $70.05 \pm 0.007^{\mathrm{d}}$ & $70.05 \pm 0.007^{\mathrm{d}}$
\end{tabular}

Values are mean of triplicate determination $(\mathrm{n}=3) \pm$ standard deviation; Means with different superscripts (a-d) are significantly different, $p<0.05$

\subsection{Anticholinesterase Activity}

The percentage of inhibition of acetylcholinesterase enzyme at $200 \mu \mathrm{g} / \mathrm{mL}$ concentration of different extracts was determined by using the Ellman method [28] (Table 3). The Soxhlet $(65.528 \%)$, maceration $(61.965 \%)$ and ultrasonic bath $(32.179 \%)$ methanol extracts exhibited the highest percentage of inhibition of acetylcholinesterase enzyme. The Soxhlet petroleum ether and chloroform extracts obtained by three extraction techniques did not show acetylcholinesterase inhibitory activity.

The anti-urease activity of methanol extract from Equisetum arvense stem at a concentration of $10 \mathrm{mg} / \mathrm{mL}$ was examined. In this study, it was found that methanol extract $(52.35 \%)$ had moderate activity compared to the hydroxyurea $(100 \%)$ which used as standard [33]. In our study, unlike the above study, the petroleum ether extract (15.302\%) of the E. telmateia aerial parts at a concentration of $12.5 \mu \mathrm{g} / \mathrm{mL}$ showed stronger anti-urease activity other other extracts. It was also found to have lower anti-urease activity compared to the 
standard (70.05\%). The anticholinesterase activity of ethanol extract from E.arvense aerial parts was examined by Ellman method [28]. According to the results, ethanol extract (IC50:3.134 $\mathrm{mg} / \mathrm{mL}$ ) exhibited lower anticholinesterase activity than galantamine (IC50: $0.003 \mathrm{mg} / \mathrm{mL}$ ) which used as standard [34]. In our study, in parallel with the study above, it was observed that the Soxhlet $(65.528 \%)$ and maceration $(61.965 \%)$ methanol extracts of the E. telmateia aerial parts at a concentration of $200 \mu \mathrm{g} / \mathrm{mL}$ showed lower anticholinesterase activity than galantamine (85.289\%). As far as we know, the present work was the first reporting on the anti-urease and anticholinesterase activity of different extracts from E. telmateia aerial parts.

Table 3. The anticholinesterase activity of different extracts of E. telmateia

\begin{tabular}{lccc}
\hline Samples & \multicolumn{3}{c}{ Enzyme inhibition $(\%)(200 \mu \mathrm{g} / \mathrm{mL})$} \\
\cline { 2 - 4 } & Ultrasonic bath & Maceration & Soxhlet \\
\hline Petroleum ether & $16.719 \pm 2.6683^{\mathrm{a}}$ & $33.489 \pm 1.7713^{\mathrm{a}}$ & $\mathrm{NA}$ \\
Chloroform & $\mathrm{NA}$ & $\mathrm{NA}$ & $\mathrm{NA}$ \\
Methanol & $32.179 \pm 6.623^{\mathrm{b}}$ & $61.965 \pm 3.0718^{\mathrm{b}}$ & $65.528 \pm 2.8942^{\mathrm{a}}$ \\
Galantamine & $85.289 \pm 0.8852^{\mathrm{c}}$ & $85.289 \pm 0.8852^{\mathrm{c}}$ & $85.289 \pm 0.8852^{\mathrm{b}}$
\end{tabular}

Values are mean of triplicate determination $(\mathrm{n}=3) \pm$ standard deviation; Means with different superscripts $(\mathrm{a}-\mathrm{c})$ are significantly different, $p<0.05$; NA: not activity

\subsection{Inhibition of the Calcium Oxalate's Crystallization}

Antioxidants have the effect of preventing stone formation by protecting endothelial cells against oxidative damage [35]. Therefore, the inhibitory effect of Soxhlet methanol extract showing strong antioxidant activity against the crystallization of calcium oxalate was compared in vitro and presented in Table 4, Figure 1 and Figure 2. The data obtained showed high efficacy in preventing nucleation of calcium oxalate crystals of methanol extract at a concentration of 5 $\mathrm{mg} / \mathrm{mL}(85.59 \%)$, but it did not show any effect at a concentration of $2 \mathrm{mg} / \mathrm{mL}$. It was also found that potassium citrate used as positive control showed $98.25 \%$ and $93.56 \%$ inhibition values at concentrations of $5 \mathrm{mg} / \mathrm{mL}$ and $2 \mathrm{mg} / \mathrm{mL}$, respectively in this study. Regarding the aggregation phase, although the methanol extract at a concentration of $5 \mathrm{mg} / \mathrm{mL}(35.31 \%)$ showed high efficacy, no effect at $2 \mathrm{mg} / \mathrm{mL}$ concentration was observed, similar to the nucleation assay. Potassium citrate has been studied at $5 \mathrm{mg} / \mathrm{mL}(85.14 \%)$ and $2 \mathrm{mg} / \mathrm{mL}$ (71.32\%) concentrations and has been found to have higher efficacy than methanol extract at both concentrations. These findings showed that the plant's methanol extract had calcium oxalate anti-crystallization activity in parallel with traditional medicine.

\subsection{Crystal Characterization}

To confirm the results we obtained in the calcium oxalate anti-crystallization assay, we followed the presence of crystals nucleation and aggregates using a light microscope (Figure 1 and Figure 2). Light microscopy analysis of the images taken during the nucleation phase shows that the number of crystals is higher in the control (without extract) state and the number and size are become becomes less important in the presence of methanol extract at a concentration of $5 \mathrm{mg} / \mathrm{mL}$ (Figure 1). Furthermore, the analysis of the images taken at the aggregation phase showed the presence of larger and more aggregates without extract, while the size and number of crystals decreased in the presence of methanol $(5 \mathrm{mg} / \mathrm{mL})$ (Figure 2). 
As far as we know, there are no reports on calcium oxalate anti-crystallization activity of E. telmateia aerial parts. The activity of calcium oxalate anti-crystallization of Soxhlet methanol extract from E. telmateia were evaluated for the first time by us.

Table 4. Calcium oxalate anti-crystallization activity of methanol extract from E. telmateia

\begin{tabular}{ccccc}
\hline $\begin{array}{c}\text { Concentration } \\
(\mathrm{mg} / \mathrm{mL})\end{array}$ & \multicolumn{2}{c}{ Nucleation $(\%)$} & \multicolumn{2}{c}{ Aggregation (\%) } \\
\hline & Methanol & Potassium citrate & Methanol & Potassium citrate \\
\hline 5 & $85.59 \pm 0.12$ & $98.25 \pm 0.65$ & $35.31 \pm 0.25$ & $85.14 \pm 0.92$ \\
2 & NA & $93.56 \pm 1.02$ & NA & $71.32 \pm 0.89$ \\
\hline
\end{tabular}

NA: not activity

A

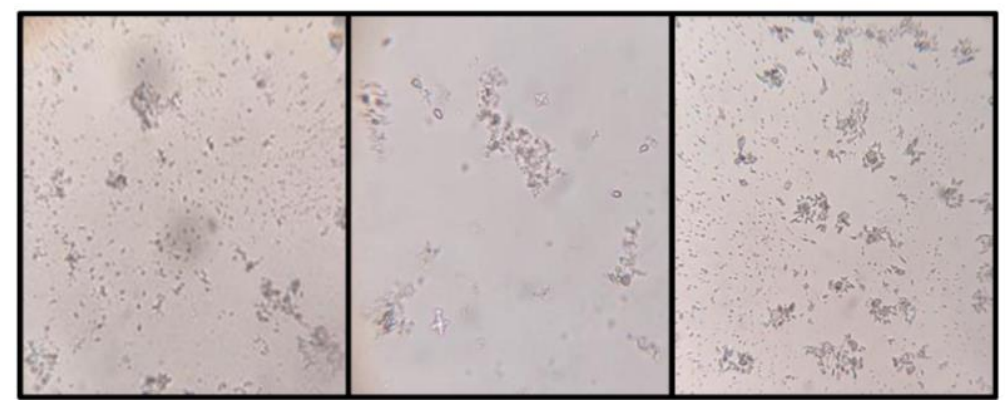

Figure 1. Calcium oxalate crystals in nucleation stages: A: Absence of inhibitor, B: methanol extract $(5 \mathrm{mg} / \mathrm{mL}), \mathrm{C}$ : methanol extract $(2 \mathrm{mg} / \mathrm{mL})$

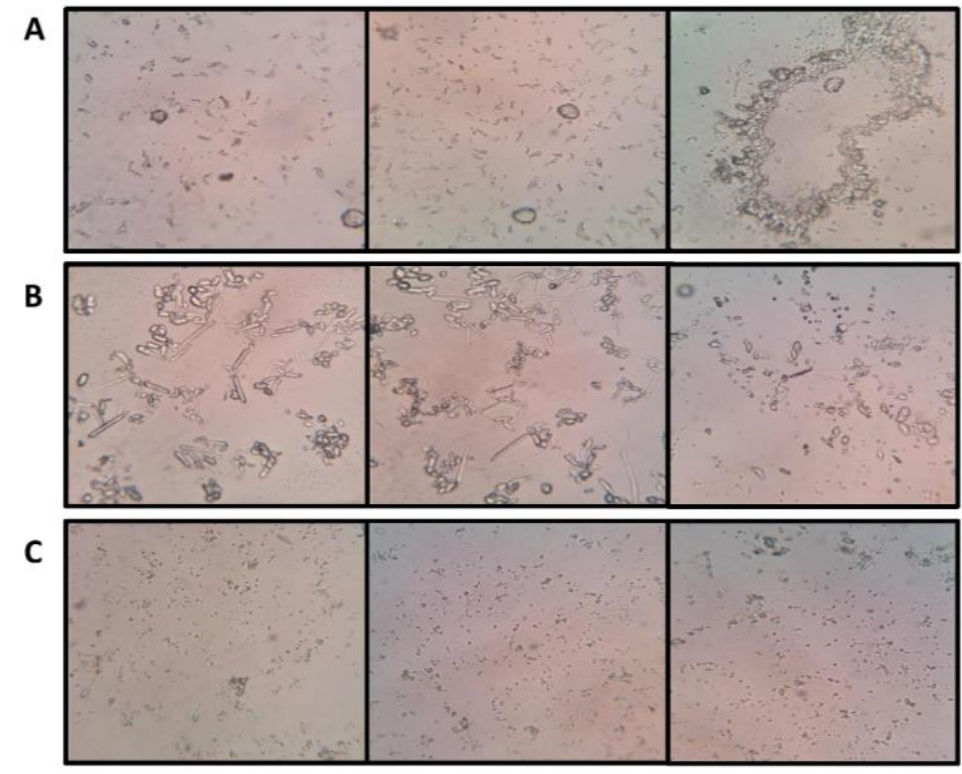

Figure 2. Calcium oxalate crystals in aggregation stages: A: Absence of inhibitor, B: methanol extract $(2 \mathrm{mg} / \mathrm{mL}), \mathrm{C}$ : methanol extract $(5 \mathrm{mg} / \mathrm{mL})$

\section{CONCLUSION}

In this study, it was found that Soxhlet methanol extracts from the aerial parts of the plant showed higher antioxidant and anticholinesterase activity than other extracts. Soxhlet 
petroleum ether extract exhibited the strongest anti-urease activity. Furthermore, it was found that Soxhlet methanol extract at a concentration of $5 \mathrm{mg} / \mathrm{mL}$ had strong inhibition of the calcium oxalate's crystallization. Therefore, methanol extract can be used in the future as an antioxidant and anticholinesterase agent as well as the treatment and /or prevention of stone formation.

\section{Acknowledgements}

This research was not received any grant or fund support from public or commercial sectors.

\section{Declaration of Conflicting Interests and Ethics}

The authors declare no conflict of interest. This research study complies with research publishing ethics. The scientific and legal responsibility for manuscripts published in IJSM belongs to the author(s).

\section{Orcid}

Turgut Taşkın (DD https://orcid.org/0000-0001-8475-6478

Beyza Nur Yilmaz (D) https://orcid.org/0000-0002-4418-3182

Ahmet Doğan (iD https://orcid.org/0000-0003-0603-5100

\section{REFERENCES}

[1]. Husby, Ch. E., Walkowiak, R.J. (2012). An Introduction to the Genus Equisetum (Horsetail) and the Class Equisetopsida (Sphenopsida) as a whole. Plant Science Bulletin, 1, 2-10.

[2]. Radojevic, I. D., Stankovic, M. S., Stefanovic, O. D., Topuzovic, M. D., Comic, L. R., Ostojic, A. M. (2012). Great Horsetail (Equisetum Telmateia Ehrh.): Active Substances Content and Biological Effects. EXCLI journal, 11, 59.

[3]. Gürbüz, İ., Yeşilada, E. (2008). In Vivo Anti-Ulcerogenic Activity of Equisetum telmateia Ehrh. Extracts Used in Turkish Folk Medicine. Turk J Biol, 32, 259-263.

[4]. Gholizadeh Nasari, F., Rassouli, M. B., Nikravesh, M. R., Moghimi, A. (2009). Neuroprotective Effects of Equisetum Telmateia in Rat. Journal of Cell and Molecular Research, 1(1), 29-34.

[5]. Yeganegi, M., Yazdi, F. T., Mortazavi, S. A., Asili, J., Behbahani, B. A., Beigbabaei, A. (2018). Equisetum telmateia Extracts: Chemical Compositions, Antioxidant Activity and Antimicrobial Effect on the Growth of Some Pathogenic Strain Causing Poisoning and Infection. Microbial pathogenesis, 116, 62-67. https://doi.org/10.1111/ejss.12559

[6]. Ramos-Tovar, E., Muriel, P. (2020). Free Radicals, Antioxidants, Nuclear Factor-E2Related Factor-2 and Liver Damage. Journal of Applied Toxicology, 40(1), 151-168. https://doi.org/10.1002/jat.3880

[7]. Ayoub, Z., Mehta, A., Mishra, S. K., Ahirwal, L. (2017). Medicinal plants as natural antioxidants: A review. Journal of botanical society, 48.

[8]. Fang, Y. Z., Yang, S., Wu, G. (2002). Free Radicals, Antioxidants and Nutrition. Nutrition, 18(10), 872-879.

[9]. Sezer, K., Keskin, M. (2014). Serbest Oksijen Radikallerinin Hastalıkların Patogenezisindeki Rolü. FÜ Săg. Bil. Vet. Dergisi, 28(1), 49-56.

[10]. Peng, C., Wang, X., Chen, J., Jiao, R., Wang, L., Li, Y.M., Zuo, Y., Liu, Y., Lei, L., Ma, K.Y., Huang, Y., Chen, Z.Y. (2014). Biology of Ageing and Role of Dietary Antioxidants. BioMed Res Int, Biology of Ageing and Role of Dietary Antioxidants. Article ID 831841, 1-13. https://doi.org/10.1155/2014/831841

[11]. Li, S., Tan, H.Y., Wang, N., Zhang, Z.J., Lao, L., Wong, C.W., Feng, Y. (2015). The Role of Oxidative Stress and Antioxidants in Liver Diseases. Int J Mol Sci, 16(11), 2608726124. https://doi.org/10.3390/ijms161125942 
[12]. Wang, F., Li, Y., Zhang, Y.J., Zhou, Y., Li, S., Li, H.B. (2016). Natural Products for the Prevention and Treatment of Hangover and Alcohol use Disorder. Molecules, 21(1), 121. https://doi.org/10.3390/molecules21010064

[13]. Butterfield, D. A., Halliwell, B. (2019). Oxidative Stress, Dysfunctional Glucose Metabolism and Alzheimer Disease. Nature Reviews Neuroscience, 20(3), 148-160. https://doi.org/10.1038/s41583-019-0132-6

[14]. Henstridge, C. M., Hyman, B. T., Spires-Jones, T. L. (2019). Beyond the Neuron-Cellular Interactions Early in Alzheimer Disease Pathogenesis. Nature Reviews Neuroscience, 20(2), 94-108. https://doi.org/10.1038/s41583-018-0113-1

[15]. Long, J.M., Holtzman, D.M. (2019). Alzheimer Disease: an Update on Pathobiology and Treatment Strategies. Cell, 179. https://doi.org/10.1016/j.cell.2019.09.001

[16]. Chey, W. D., Leontiadis, G. I., Howden, C. W., Moss, S. F. (2017). ACG Clinical Guideline: Treatment of Helicobacter Pylori Infection. American Journal of Gastroenterology, 112(2), 212-239. https://doi.org/10.1038/ajg.2016.563

[17]. Holleczek, B., Schöttker, B., Brenner, H. (2019). Helicobacter Pylori Infection, Chronic Atrophic Gastritis and Risk Of Stomach and Esophagus Cancer: Results from the Prospective Population-Based ESTHER Cohort Study. International journal of cancer. 146(10), 2773-2783 https://doi.org/10.1002/ijc.32610

[18]. Mimica-Dukić, N., Simin, N., Orčić, D., Lesjak, M., Knežević, P., Aleksić, V., Buzas, K. (2018). Therapeutic Efficiency of Essential Oils Against Helicobacter pylori Infections. Facta Universitatis, Series Physics, Chemistry and Technology, 16(1), 29.

[19]. Chow, K., Dixon, J., Gilpin, S., Kavanagh, J. P., Rao, P. N. (2004). Citrate Inhibits Growth of Residual Fragments in an In Vitro Model of Calcium Oxalate Renal Stones. Kidney international, 65(5), 1724-1730. https://doi.org/10.1111/j.1523-1755.2004.00566.x

[20]. Wesson, J. A., Johnson, R. J., Mazzali, M., Beshensky, A. M., Stietz, S., Giachelli, C., Hughes, J. (2003). Osteopontin is a Critical Inhibitor of Calcium Oxalate Crystal Formation and Retention in Renal Tubules. Journal of the American Society of Nephrology, 14(1), 139-147. https://doi.org/10.1097/01.ASN.0000040593.93815.9D

[21]. Chien, Y. C., Mansouri, A., Jiang, W., Khan, S. R., Gray, J. J., McKee, M. D. (2018). Modulation of Calcium Oxalate Dihydrate Growth by Phosphorylated Osteopontin Peptides. Journal of structural biology, 204(2), 131-144. https://doi.org/10.1016/j.jsb.2018.07.010

[22]. Hoyer, J. R., Asplin, J. R., Otvos Jr, L. (2001). Phosphorylated Osteopontin Peptides Suppress Crystallization by Inhibiting the Growth of Calcium Oxalate Crystals. Kidney international, 60(1), 77-82. https://doi.org/10.1046/j.1523-1755.2001.00772.x

[23]. Akyol, E. (2016). Kalsiyum Oksalat Monohidrat Kristal Büyümesine Karahindiba ( Taraxacum officinale) Bitkisinin Etkisinin İncelenmesi. I ğdır Üniversitesi Fen Bilimleri Enstitüsü Dergisi, 6(3), 97-105.

[24]. Barros, M. E., Schor, N., Boim, M. A. (2003). Effects of an Aqueous Extract from Phyllantus niruri on Calcium Oxalate Crystallization In Vitro. Urological research, 30(6), 374-379. https://doi.org/10.1007/s00240-002-0285-y

[25]. Re, R., Pellegrini, N., Proteggente, A., Pannala, A., Yang, M., Rice-Evans, C. (1999). Antioxidant Activity Applying an İmproved ABTS Radical Cation Decolorization Assay. Free radical biology and medicine, 26(9-10), 1231-1237.

[26]. Apak, R., Güçlü, K., Özyürek, M., Karademir, S. E. (2004). Novel Total Antioxidant Capacity İndex for Dietary Polyphenols and Vitamins $\mathrm{C}$ and E, Using Their Cupric İon Reducing Capability in the Presence of Neocuproine: CUPRAC Method. Journal of agricultural and food chemistry, 52(26), 7970-7981. https://doi.org/10.1021/jf048741x 
[27]. Taşkın, D., Taşkın, T., Rayaman, E. (2018). Phenolic Composition and Biological Properties of Achillea nobilis L. subsp. neilreichii (Kerner) Formanek. Industrial crops and products, 111, 555-562. https://doi.org/10.1016/j.indcrop.2017.11.022

[28]. Ellman, G. L., Courtney, K. D., Andres Jr, V., Featherstone, R. M. (1961). A New and Rapid Colorimetric Determination of Acetylcholinesterase Activity. Biochemical pharmacology, 7(2), 88-95.

[29]. Bawari, S., Sah, A. N., Tewari, D. (2018). Antiurolithiatic Activity of Daucus carota: an In Vitro Study. Pharmacognosy Journal, 10(5), 880-884. https://doi.org/10.5530/pj.2018.5.148

[30]. Lopez, V., Akerreta, S., Casanova, E., García-Mina, J., Cavero, R., Calvo, M. (2008). Screening of Spanish Medicinal Plants for Antioxidant and Antifungal Activities. Pharmaceutical Biology, 46(9), 602-609. https://doi.org/10.1080/13880200802179634

[31]. Correia, H., González-Paramás, A., Amaral, M. T., Santos-Buelga, C., Batista, M. T. (2005). Characterisation of Polyphenols by HPLC-PAD-ESI/MS And Antioxidant Activity in Equisetum telmateia. Phytochemical Analysis: An International Journal of Plant Chemical and Biochemical Techniques, 16(5), 380-387. https://doi.org/10.1002.pca.864

[32]. Salihoglu, E.M., Akaydın, G., Can, E.C., Akaydın, S.Y. (2012). Evaluation of Antioxidant Activity of Various Herbal Folk Evaluation Medicine. FABAD Journal of Pharmaceutical Sciences, 35, 59-67.

[33]. Nabati, F., Mojab, F., Rezaei, MH., Bagherzadeh, K., Amanlou, M., Yousefi, B. (2012). Large scale screening of commonly used Iranian traditional medicinal plants against urease activity. DARU Journal of Pharmaceutical Science, 20, 1-9. https://doi.org/10.1186/2008-2231-20-72

[34]. Miguel, M., Bouchmaaa, N., Aazza, S., Gaamoussi, F., Lyoussi, B. (2014). Antioxidant, Anti-Inflammatory and Anti-Acetylcholinesterase Activities of Eleven Extracts of Moroccan Plants. Fresenius Environmental Bulletin, 23(6), 1-14.

[35]. Ahmed, S., Hasan, M. M., Khan, H., Mahmood, Z. A., Patel, S. (2018). The Mechanistic Insight of Polyphenols in Calcium Oxalate Urolithiasis Mitigation. Biomedicine \& Pharmacotherapy, 106, 1292-1299. https://doi.org/10.1016/j.biopha.2018.07.080 